\title{
Phylogenetic Analysis of Isolates of Pasteurella pneumotropica from Laboratory Animals Based on the gyrB Gene Sequence
}

\author{
Nobuhito HAYASHIMOTO, Masami UENO, Akira TAKAKURA, \\ and Toshio ITOH
}

\begin{abstract}
ICLAS Monitoring Center, Central Institute for Experimental Animals, 1430 Nogawa, Miyamae-ku, Kawasaki-shi, Kanagawa 216-0001, Japan
\end{abstract}

\begin{abstract}
Phylogenetic analysis using the gyrB sequence was performed to investigate the genetic relevance among 49 isolates of $P$. pneumotropica. In the phylogeny, the isolates were clearly classified into three groups as follows: group $A$ for the isolates of biotype Jawetz derived from mice, group $B$ for the isolates of biotype Jawetz derived from rats, and group $C$ for the isolates of biotype Heyl. These results suggest that the gyrB sequence of $P$. pneumotropica differs between the isolates of two biotypes, and also between the isolates derived from mice and rats in the biotype Jawetz.
\end{abstract}

Key words: gyrB gene, Pasteurella pneumotropica, phylogenetic analysis

Pasteurella pneumotropica ( $P$. pneumotropica) is an opportunistic pathogen in immunocompetent mice and rats, and it is known to cause clinical disorders in immunodeficient mice and rats $[1,3,5,6,12,13]$. On the basis of these facts, it is considered to be a routine test item for laboratory mice and rats [7]. In routine tests, identification of $P$. pneumotropica has been performed based on its biological and genetic traits [2, 11, 18]. However, confusion has sometimes arisen in the identification of $P$. pneumotropica because of the very wide variety of biological and genetic traits [7]. In taxonomy, $P$. pneumotropica has been regarded as a heterogenous species containing several unclassified new species [15]. Although some reports have shown heterogenicity of biochemical traits in field isolates of $P$. pneumotropica
[2], very few reports have shown heterogenicity of genetic traits in field isolates.

Recently, the gene encoding the DNA gyrase subunit $\mathrm{B}$ protein $(\mathrm{gyr} B)$ sequence has been reported to be more useful than the $16 \mathrm{~S}$ rRNA sequences for comparing closely related bacterial strains including members of the genera Acinetobacter [20], Fusobacterium [9], Mycobacterium [10], Pseudomonas [19, 21] and Vibrio [17]. Furthermore, it was also reported that the phylogenetic distance based on $g y r B$ sequences shows a close correlation with total genome homology analyzed by DNA-DNA hybridization in certain bacterial species [16]. In this study, we performed phylogenetic analysis using the $g y r B$ sequence to investigate the genetic relevance among 49 isolates of $P$. pneumotropica. 
Forty-nine isolates were collected from 8 facilities in Japan (Table 1). All isolates showed Gram-negative coccobacillus and formed grayish-white or yellow, smooth, low convex colonies 3-5 $\mathrm{mm}$ in diameter on $5 \%$ horse blood agar. Identification and biotyping was performed by a biochemical test kit (ID test HN 20 rapid; Nissui Pharmaceutical Co., Tokyo, Japan) and fermentation test of $\mathrm{L}(+)$ arabinose and $\mathrm{D}(+)$ melibiose using phenol-red broth (Merck Ltd., Darmstadt, Germany). P. pneumotropica biotype Jawetz (ATCC35149) and $P$. pneumotropica biotype Heyl (CNP160) were used as reference strains. Actinobacillus ureae (ATCC29693) was also used as the organism of outgroups in the phylogenetic tree.

Chromosomal DNA of each isolate was purified by phenol-chloroform extraction and ethanol precipitation. The dried DNA pellets were dissolved in Tris-EDTA buffer ( $\mathrm{pH}$ 7.5) and used as DNA templates. The partial coding region of the $\operatorname{gyr} B$ gene was amplified using the primers, UP1 (5'GAAGTCATCATGACCGTTCTGCAYGCNGGNGG NAARTTYGA-3') and UP2r (5'-AGCAGGGTA CGGATGTGCGAGCCRTCNACRTCNGCRTCNGT CAT-3') [19]. DNA sequencing was performed by dideoxy chain termination methods using an ABI Prism BigDye Terminator v3.1 Cycle Sequencing Kit (Applied Biosystems, Foster City, CA, U.S.A.) and sequence primers UP1S (5'-GAAGTCATCATGA CCGTTCTGCA-3') and UP2rS (5'-AGCAGGGTA CGGATGTGCGAGCC-3') [19]. Sequence reactions were analyzed on a PRIZM 310 Genetic analyzer (Applied Biosystems). The gyrB gene sequences were assembled with sequence analysis software, DNASIS (Hitachi Software Engineering Co., Kanagawa, Japan). The phylogenetic tree was created using the CLUSTAL $\mathrm{W}$ version 1.83 computer program and Tree View version 1.6.6 computer program by the neighbor-joining method. The stability of the grouping of the phylogenetic tree was assessed by 1,000 fold boot-strapping. The nucleotide sequence data of $P$. pneumotropica biotype Jawetz (ATCC35149), biotype Heyl (CNP160) and A. ureae (ATCC29693) will appear in the DDBJ databases with the following accession numbers: AB213398, AB213399 and AB213401.

The partial sequences of $g y r B$ fragments from the two reference strains and all isolates were determined in the range of $1046 \mathrm{bp}-1130 \mathrm{bp}$, and they were aligned
Table 1. Isolates used in this study

\begin{tabular}{|c|c|c|c|}
\hline Isolates & Biotypes & Origin & Facility \\
\hline No. 1 & \multirow{35}{*}{ Jawetz } & Mouse & A \\
\hline No. 2 & & Mouse & A \\
\hline No. 3 & & Mouse & A \\
\hline No. 4 & & Mouse & A \\
\hline No. 5 & & Mouse & A \\
\hline No. 6 & & Mouse & B \\
\hline No. 7 & & Mouse & $\mathrm{D}$ \\
\hline No. 8 & & Mouse & $\mathrm{D}$ \\
\hline No. 9 & & Mouse & $\mathrm{E}$ \\
\hline No. 10 & & Mouse & $\mathrm{F}$ \\
\hline No. 11 & & Mouse & $\mathrm{G}$ \\
\hline No. 12 & & Mouse & $\mathrm{H}$ \\
\hline No. 13 & & Mouse & $\mathrm{H}$ \\
\hline No. 14 & & Mouse & $\mathrm{H}$ \\
\hline No. 15 & & Mouse & $\mathrm{H}$ \\
\hline No. 16 & & Mouse & $\mathrm{H}$ \\
\hline No. 17 & & Mouse & $\mathrm{H}$ \\
\hline No. 18 & & Mouse & $\mathrm{H}$ \\
\hline No. 19 & & Mouse & $\mathrm{H}$ \\
\hline No. 20 & & Mouse & $\mathrm{H}$ \\
\hline No. 21 & & Mouse & $\mathrm{H}$ \\
\hline No. 22 & & Mouse & $\mathrm{H}$ \\
\hline No. 23 & & Mouse & $\mathrm{H}$ \\
\hline No. 24 & & Mouse & $\mathrm{H}$ \\
\hline No. 25 & & Mouse & $\mathrm{H}$ \\
\hline No. 26 & & Rat & A \\
\hline No. 27 & & Rat & A \\
\hline No. 28 & & Rat & $\mathrm{C}$ \\
\hline No. 29 & & Rat & $\mathrm{D}$ \\
\hline No. 30 & & Rat & $\mathrm{E}$ \\
\hline No. 31 & & Rat & $\mathrm{F}$ \\
\hline No. 32 & & Rat & $\mathrm{G}$ \\
\hline No. 33 & & Rat & G \\
\hline No. 34 & & Rat & G \\
\hline No. 35 & & Rat & $\mathrm{H}$ \\
\hline No. 36 & \multirow{14}{*}{ Heyl } & Mouse & $\mathrm{H}$ \\
\hline No. 37 & & Mouse & $\mathrm{H}$ \\
\hline No. 38 & & Mouse & $\mathrm{H}$ \\
\hline No. 39 & & Mouse & $\mathrm{H}$ \\
\hline No. 40 & & Mouse & $\mathrm{H}$ \\
\hline No. 41 & & Mouse & $\mathrm{H}$ \\
\hline No. 42 & & Mouse & $\mathrm{H}$ \\
\hline No. 43 & & Rat & $\mathrm{G}$ \\
\hline No. 44 & & Rat & G \\
\hline No. 45 & & Rat & $\mathrm{H}$ \\
\hline No. 46 & & Rabbit & $\mathrm{G}$ \\
\hline No. 47 & & Guinea pig & $\mathrm{H}$ \\
\hline No. 48 & & Hamster & $\mathrm{H}$ \\
\hline No. 49 & & Hamster & $\mathrm{H}$ \\
\hline
\end{tabular}


and adjusted to 1,000 bp for construction of the phylogenetic tree. In the phylogenetic tree, the 49 isolates tested were clearly classified into three groups from A to $\mathrm{C}$ (Fig. 1). All isolates of biotype Jawetz derived from mice were classified in group A. All isolates of biotype Jawetz from rats were classified in group B, and all isolates of biotype Heyl were classified in group C. The degree of sequence similarity of the isolates in

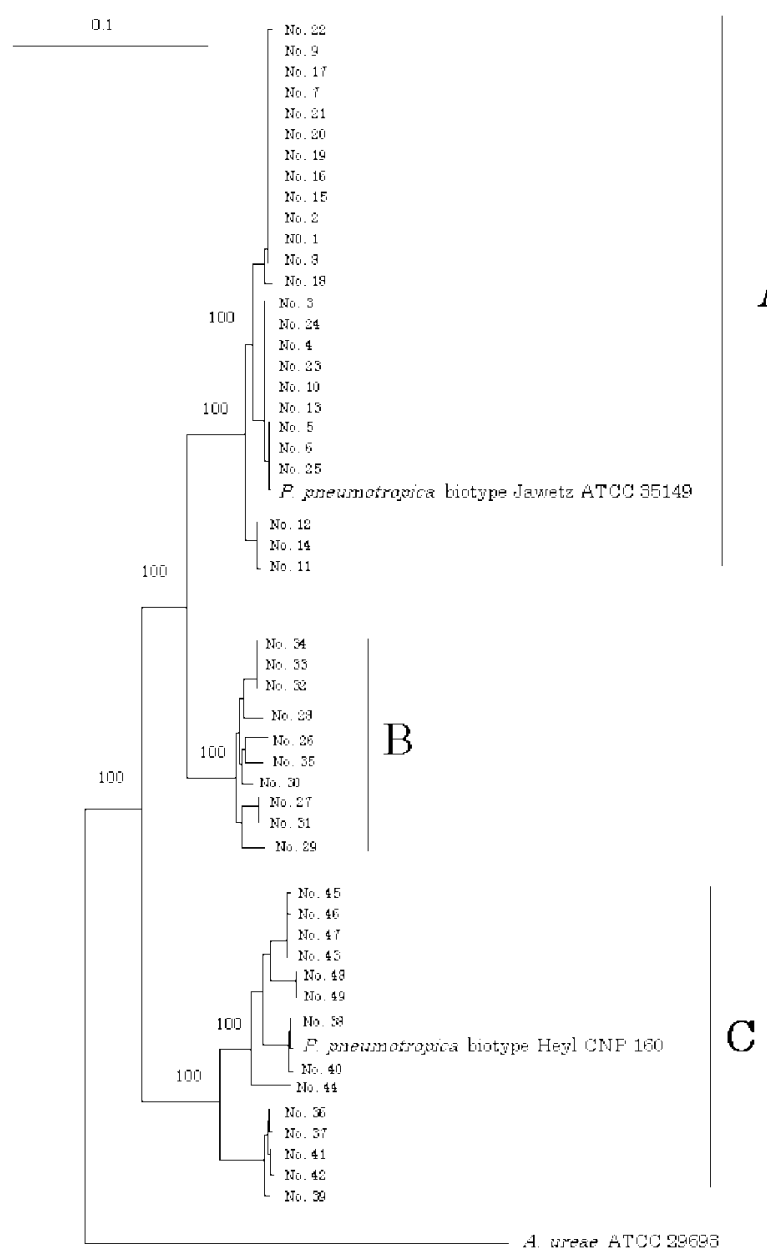

Fig. 1. Unrooted neighbor-joining tree based on gyrB gene sequences showing the phylogenetic relationships of two reference strains, Pasteurella pneumotropica biotype Jawetz and $P$. pneumotropica biotype Heyl, and 49 isolates of $P$. pneumotropica. The sequences were compared with that of Actinobacillus ureae as an outgroup. The numbers on the dendrogram are the percentage occurrence in 1,000 boot-strapped trees; only $100 \%$ values are given. The scale bar indicates an evolutionary distance of a 0.1 difference between sequences, determined by measuring the lengths of the horizontal lines connecting two organisms. each group were A: $97.3-99.9 \%$, B: $96.1-99.7 \%$ and C: $93.1-99.7 \%$. These were higher than those of the isolates in different groups (A and B: 91.4-93.2\%, B and C: $86.2-89.4 \%$, A and C: 86.9-88.6\%). Some regions of amino acid sequences showing differences among the isolates in each group are indicated for selected strains and isolates in Fig. 2. These results suggest that the gyrB gene sequence of $P$. pneumotropica differs between the isolates of two biotypes, and also differs between the isolates derived from mice and rats in biotype Jawetz.

Our recent study on the phylogenetic tree using $16 \mathrm{~S}$ rRNA sequences of 35 strains of $P$. pneumotropica did not clearly classify the strains into groups that agreed with their derivations, although tendencies were observed [8]. Consequently, the $g y r B$ gene sequence may be useful for subclassification of $P$. pneumotropica at the strain or isolate level.

The correlation between some housekeeping genes $(a t p D$, infB, rpoB) and 16S rRNA genes at the species level were reported as low for $P$. pneumotropica in an evolutional study [4]. The correlation between the $\mathrm{gyr} B$ gene and 16S rRNA gene for $P$. pneumotropica at the species level has never been reported, and it can not be inferred from our limited study.

In this study, the genetic relevance of the $\operatorname{gyr} B$ genes among the isolates of $P$. pneumotropica was shown. Genetic information of $P$. pneumotropica at the isolate

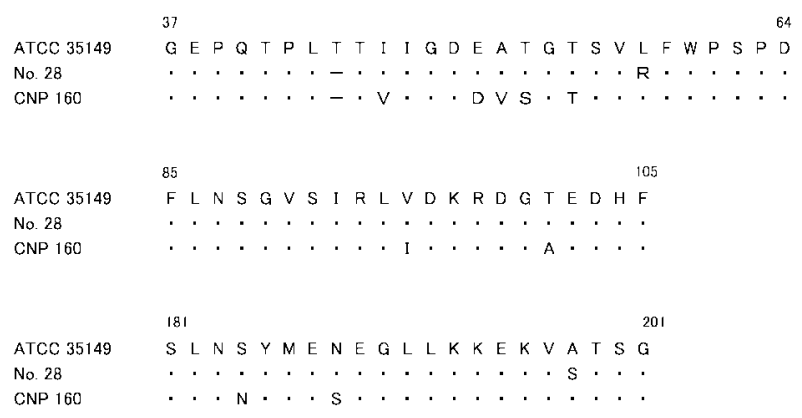

Fig. 2. Some regions of amino acid sequences showed differences among the isolates in each group for selected strains and isolates. ATCC 35149 was classified in group A, and No. 28 derived from rats and CNP 160 were classified in groups $\mathrm{B}$ and $\mathrm{C}$, respectively in the phylogeny in this study. Amino acids identical to those of ATCC 35149 are indicated with dots, and gaps are indicated with dashes. Amino acid numbering corresponds to the sequence of ATCC 35149. 
level is insufficient. Therefore, our results will be useful as genetic information for development of a new typing procedure for $P$. pneumotropica.

\section{Ackowledgments}

The authors thank the Pp working group of Japan (Mr. T. Aiba and Dr. T. Narita, Sankyo Co.; Dr. K. Itoh, The University of Tokyo; Ms. M. Kato, Charles River Japan; Dr. E. Kawamoto, Tokyo Medical University; Mr. S. Kiyokawa, CLEA JAPAN; Ms. Y. Morichika, Japan SLC; Dr. T. Muraguchi, Kyoto University; Dr. Y. Okajima, Mercian Cleantec) and Dr. Ken-ichi Yagami of Tsukuba University for providing strains.

\section{References}

1. Artwohi, J.E., Frynn, J.C., Bunte, R.M., and Angen, O. 2000. Contemp. Topics. 39: 39-41.

2. Boot, R. and Bisgaard, M. 1994. Lab. Anim. 29: 314-319.

3. Branger, J., Knapp, S., Weijier, S., Leemans, J.C., Pater, J.M., Speelman, P., Florquin, S., and van der Poll, Tom. 2004. Infect. Immun. 72: 788-794.

4. Christensen, H., Kuhnert, P., Olsen, J-E., and Bisgaard, M. 2004. Int. J. Syst. Evol. Microbiol. 54: 1601-1609.

5. Goelz, M.F., Thigpen, J.E., Mahler, J., Rogers, W.P., Locklear, J., Weigler, B.J., and Forsythe, D.B. 1996. Lab. Anim. Sci. 46: 280-285.

6. Hart, M.L., Mosier, D.A., and Chapes, K. 2003. Infect. Immun. 71: 663-670.
7. Hayashimoto, N., Aiba, T., Itoh, K., Kato, M., Kawamoto, E., Kiyokawa, S., Morichika, Y., Muraguchi, T., Narita, T., Okajima, Y., Takakura, A., and Itoh, T. 2005. Exp. Anim. 54: 123-129.

8. Hayashimoto, N., Takakura, A., and Itoh, T. 2005. Curr. Microbiol. 51: 239-243.

9. Jin, J., Haga, T., Shinjo, T., and Goto, Y. 2004. J. Vet. Med. Sci. 66: 1243-1245.

10. Kasai, H., Ezaki, T., and Harayama, S. 2000. J. Clin. Microbiol. 38: 301-308.

11. Kodjo, A., Villard, L., Veillet, F., Escande, F., Borges, E., Maurin, F., Bonnod, J., and Richard, Y. 1999. Lab. Anim. Sci. 49: 49-53.

12. Moore, G.J. and Aldred, P. 1978. Lab. Anim. 12: 227-228.

13. Needham, J.R. and Cooper, J.E. 1975. Lab. Anim. 9: 197200.

14. Nozu, R., Goto, K., Ohashi, H., Takakura, A., and Itoh, T. 1999. Exp. Anim. 48: 51-54.

15. Olsen, I., Dewhrist, F.E., Paster, B.J., and Busse, H.J. 2005. pp. 851-866. In: Bergey's Manual of Systematic Bacteriology, 2nd Ed., Vol. 2 (Garrity, G.M. ed.), Springer, New York.

16. Suzuki, M., Nakagawa, Y., Harayama, S., and Yamamoto, S. 2001. Int. J. Syst. Evol. Microbiol. 51: 1639-1652.

17. Venkateswaran, K., Dohmoto, N., and Harayama, S. 1998. Appl. Environ. Microbiol. 64: 681-687.

18. Wang, R-F., Campbell, W., Cao, W-W., Summage, C., Steele, R.S., and Cerniglia, C.E. 1996. Lab. Anim. Sci. 46: 81-85.

19. Yamamoto, S. and Harayama, S. 1995. Appl. Environ. Microbiol. 61: 1104-1109.

20. Yamamoto, S. and Harayama, S. 1996. Int. J. Syst. Bacteriol. 46: 506-511.

21. Yamamoto, S. and Harayama, S. 1998. Int. J. Syst. Bacteriol. 48: 813-819. 